\title{
Effect of the application of ultrasound on sarcoplasmic proteins from giant squid (Dosidicus gigas) mantle
}

\author{
Enzo ALDORADIN-PUZA ${ }^{1}$, Alma Gloria SALAZAR-FUENTES², Guillermo RODRÍGUEZ-OLIBARRÍA², \\ Francisco RODRÍGUEZ-FELIX ${ }^{2}$, Carlos Gregorio BARRERAS-URBINA², Enrique MARQUEZ-RIOS ${ }^{2 *}$ (D)
}

\begin{abstract}
This research studies the application of ultrasound (US) on sarcoplasmic proteins from giant squid (Dosidicus gigas) mantle and its effect on its functional properties. US was applied during 30,60 and $90 \mathrm{~s}$. A decrease was observed in the emulsifying activity index (EAI), an increase in the emulsifying stability index (ESI), an increase in the foaming capacity (FC) and a decrease in the foaming stability (FS). In addition, the application of US increased the surface hydrophobicity (So) and decreased the viscosity with the increase in temperature. Functional properties of sarcoplasmic giant squid mantle proteins increase with the application of ultrasound.
\end{abstract}

Keywords: sarcoplasmic proteins; giant squid; ultrasound.

Practical Application: Food industry has interest in ultrasound to improve functional properties of proteins.

\section{Introduction}

The giant squid (Dosidicus gigas) is a mollusk that represents one of the most important fisheries in the Pacific Ocean. Its commercial appeal lies in its low cost, low fat content, its white meat and its high performance after evisceration. These characteristics make this organism a good species for the possible production of surimi or protein isolates. Most surimi is made from bottom marine fish, such as Pacific whiting and Alaska pollock (Park, 2005); however, due to its growing demand, the giant squid is being studied as an alternative raw material. During its elaboration, soluble protein (sarcoplasmic protein) is discarded, which in squid mantle oscillates around 30\% (Dihort-Garcia et al., 2011).

In order to reduce the amount of effluents from the surimi industry around the world, previous studies have focused on the recovery of sarcoplasmic proteins (SP). Therefore, their recovery not only decreases pollution problems, also promote a better usage of marine resources (Yongsawatdigul \& Hemung, 2010). Several studies indicate that these proteins can be used in the pharmaceutical area or in the food sector, mainly as additives (López-Enriquez et al., 2015; Sett et al., 2016).

It has been reported that SP affect the gelling property of myofibrillar proteins, so their study has focused on knowing other functional or technological properties. It has been documented that SP can provide good emulsifying or foaming properties (López-Enriquez et al., 2015: Villamonte et al., 2016). In a research, López-Enriquez et al. (2015) studied the effect of $\mathrm{pH}$ and ionic strength on the emulsifying and foaming property of SP of the squid mantle, concluding that these properties can be enhanced by varying the aforementioned factors. However, recently, the improvement of these functional properties has been reported without the addition of any component or additive to the protein solution. The application of ultrasonic pulses is one of the technologies that has provided the best results. This technology has been used in food technology as a non-thermal technology to inactivate enzymes and microorganisms, which enhance the shelf life, mainly in liquid systems as dairy foods (Guimarães et al., 2019a; Guimarães et al., 2019b; Khairi et al., 2018). However, last years ultrasound (US) has been widely used to modify the functional properties of proteins, degassing of liquid foods, among others (Higuera-Barraza et al., 2016; Hu et al., 2013). Different studies have reported the application of high intensity ultrasound on milk (Ahmad et al., 2019; Balthazar et al., 2019), vegetable proteins (Yang et al., 2018; O'Sullivan et al., 2016; Hu et al., 2013; Rodriguez-Turienzo et al., 2012), myofibrillar proteins of terrestrial animals (Amiri et al., 2018; Wang et al., 2017), fish myofibrillar proteins (Tian et al., 2015) and cephalopods (Higuera-Barraza et al., 2017; Valdez-Hurtado et al., 2019). However, so far, no studies have been reported about the ultrasound application on the sarcoplasmic proteins from giant squid (Dosidicus gigas). Therefore, the present study evaluated the application of US on SP of the giant squid mantle and its effect on the functional properties (emulsification and foam formation), hydrophobicity and viscosity.

\section{Materials and methods}

\subsection{Raw materials}

Samples of giant squid (Dosidicus gigas) were commercially obtained at a local fish market (at $-20{ }^{\circ} \mathrm{C}$ ). Mantles showed an average weight and length of $9.5 \pm 0.2 \mathrm{~kg}$ and $79 \pm 2 \mathrm{~cm}$, 
respectively. Samples were placed in plastic bags and stored at $-20{ }^{\circ} \mathrm{C}$ for further analysis.

\subsection{Obtaining sarcoplasmic proteins}

Mantles were thawed at $4-5^{\circ} \mathrm{C}$ for $12 \mathrm{~h}$. Each mantle was considered as a repetition of the experiment. It was chopped into small pieces, and homogenized with cold distilled water $\left(\leq 4{ }^{\circ} \mathrm{C}\right)$ at ratio of $1: 3$ (mantle:water). This was homogenized at $1000 \mathrm{rpm}$ for $2 \mathrm{~min}$ using a homogenizer (Wisd, WiseTis HG-15D, Witeg, Germany). The homogenate was centrifuged at $12,000 \times \mathrm{g}$ for $20 \mathrm{~min}$ at $4^{\circ} \mathrm{C}$ (Thermo Scientific, Sorvall Biofuge Stratos, Hanau, Germany). The supernatant was regarded as the sarcoplasmic proteins (SP). Protein content was determined according to the method of Lowry et al. (1951) using bovine serum albumin (BSA) as the standard.

\subsection{Sonication treatment}

Samples (protein solution) were sonicated using an equipment with a $0.636 \mathrm{~cm}$ diameter titanium probe (Digital Sonifier 250; Branson, México). For this, $20 \mathrm{kHz}$ and $20 \%$ amplitude (17 W) were used. Protein solution was adjusted to $3 \mathrm{mg} / \mathrm{mL}$. Then, $20 \mathrm{~mL}$ were sonicated for $0,30,60$, and $90 \mathrm{~s}$. During the sonication temperature was maintained within the range of $0-3^{\circ} \mathrm{C}$ using an ice bath.

\subsection{Emulsifying Activity Index (EAI) and Emulsion Stability Index (ESI)}

The emulsifying activity index (EAI) and emulsion stability index (ESI) were determined using the methodology described by Pearce \& Kinsella (1978). Protein concentration was adjusted to $3 \mathrm{mg} / \mathrm{mL}$, and it was mixed with canola oil at a ratio of 1:1 to obtain a volume of $10 \mathrm{~mL}$. Then, it was homogenized at $12,000 \mathrm{rpm}$ for $1 \mathrm{~min}$, using the a homogenizer. After that, the EAI was determined by taking an aliquot of $200 \mu \mathrm{L}$ from the aqueous layer and diluted $1: 40$ with $0.1 \%$ of sodium dodecyl sulfate (SDS). Then, the absorbance was measured at $500 \mathrm{~nm}$ using a spectrophotometer (Cary 50; Varian, Walnut Creek, CA, USA).

After the formation of the emulsion (10 min) the ESI was determined. Then, $100 \mu \mathrm{L}$ were taken from the lower layer and the absorbance at $500 \mathrm{~nm}$ was registered (Cary 50; Varian, Walnut Creek, CA, USA).

\subsection{Foaming Capacity (FC) and Foam Stability (FS)}

Foaming capacity (FC) was estimated according to the methodology of Coffmann \& Garciaj (1977). For this, $50 \mathrm{~mL}$ $(3 \mathrm{mg} / \mathrm{mL})$ of protein solution was used. The solution was mixed at 1000 rpmin a domestic blender (Osterizer, Sunbeam Corp. Ltd., Toronto, Ont, Canada). Next, it was immediately poured into a graduated cylinder to determine the FC. FS was evaluated by monitoring foam volume after $60 \mathrm{~min}$.

\subsection{Viscosity}

The viscosity of the protein solutions was evaluated using a rheometer (model MCR 102; Anton-Paar GmbH, Graz, Austria). For this, $20 \mathrm{~mL}$ of sample at a concentration of $3.0 \mathrm{mg} / \mathrm{mL}$ were used. Then, a heating scan was done from 10 to $90^{\circ} \mathrm{C}$ at a heating rate of $5{ }^{\circ} \mathrm{C} / \mathrm{min}$. Results were plotted as viscosity (Pa.s) versus temperature $\left({ }^{\circ} \mathrm{C}\right)$.

\subsection{Surface hydrophobicity (SoANS)}

Surface hydrophobicity was determined as describe by Kato \& Nakai (1980)with modifications, using ANS (1-Anilline-8-Naftalen-Sulphonate) as probe. The protein $(3 \mathrm{mg} / \mathrm{mL})$ was dissolved in phosphate buffer (3.5 $\mathrm{mM} \mathrm{KH}_{2} \mathrm{PO}_{4}$ and $15.6 \mathrm{mM} \mathrm{Na}_{2} \mathrm{HPO}_{4}$ ) $\mathrm{pH}$ 7.5. This protein solution was diluted to obtain protein concentrations ranged from 0.325 to $1.5 \mathrm{mg} / \mathrm{mL}$. Then, $4 \mathrm{~mL}$ were mixed with $80 \mu \mathrm{L}$ of $2 \mathrm{mM}$ ANS, which was dissolved in buffer $(20 \mathrm{mM}$ Tris- $\mathrm{HCl}$ buffer, $\mathrm{pH}$ 7.0). The fluorescence intensity was determined using a spectrophotometer (LS 55; Perkin-Elmer, NJ, USA). Excitation and emission wavelengths of 414 and $500 \mathrm{~nm}$, respectively, were used.

\subsection{Statistical analysis}

The experiment was done three time $(\mathrm{n}=3)$, and all the determinations were realized in triplicate. Data were analysed through an analysis of variance (ANOVA). When required, multiple Tukey comparisons were performed with a significance level of 95\%, using software JMP ver. 8 for Windows (SAS Institute, Inc., Cary, NC, USA). Data were presented as mean \pm standard deviation.

\section{Results and discussion}

\subsection{Obtaining sarcoplasmic proteins}

The procedure described by Encinas-Arzate et al. (2014) was used for the extraction of SP. It consisted in carrying out a single wash of the giant squid mantle, homogenizing the muscle with distilled water in a ratio of 1:3 (mantle:water) and then centrifuged. The supernatant obtained after the centrifugation of the giant squid mantle was considered as the sarcoplasmic fraction, which presented a protein concentration of $3.5 \mathrm{mg} / \mathrm{mL}$.

\subsection{Emulsifying property}

The most common food emulsions are of oil-in-water type, where the oil is the dispersed phase and, it is in the form of small droplets or dispersed globules, while water is the continuous dispersing phase (Sikorski, 2007). The emulsifying properties of the sarcoplasmic proteins were evaluated according to emulsifying activity index (EAI) and emulsifying stability index (ESI), for which sarcoplasmic protein solutions $(3 \mathrm{mg} / \mathrm{mL})$, previously treated with ultrasound pulses were used.

\subsection{Emulsifying activity index}

Emulsifying activity index (EAI) represents the capacity of a protein to be absorbed at the interface of the fat globules and the aqueous phase. It is directly related to the surface area $\left(\mathrm{m}^{2}\right)$ stabilized per unit weight $(\mathrm{g})$ of protein. The EAI depends on the volume of oil, protein concentration and the type of equipment used to produce the emulsion, therefore, the EAI not only 
depends on the protein used, but it is a property of the system as a whole (Pearce \& Kinsella, 1978).

In this study, significant differences $(\mathrm{P}<0.05)$ in the EAI were found as a consequence of US application on the SP from giant squid mantle proteins (Figure 1). The control SP presented an EAI of $284.63 \mathrm{~m}^{2} \mathrm{~g}^{-1}$, being higher than the EAI detected in SP subjected to US, i.e., after $30 \mathrm{~s}$, it decreased approximately $30 \%$, while at 60 and $90 \mathrm{~s}$, it decreased 4 and 7\%, respectively. This contrasts with studies in other types of proteins, where they indicate a significant increase in EAI during the US application. In this sense, Yanjun et al. (2014) found an increase in 40\% of the EAI when studying milk proteins after applying $2 \mathrm{~min}$ of US $(20 \mathrm{kHz}, 50 \%$ amplitude). In another research, Higuera-Barraza et al. (2017) showed a $76 \%$ increase in EAI in giant squid mantle myofibrillar proteins after applying US (20 kHz; 20 and $40 \%$ amplitude; 30,60 and 90 s). This discrepancy can be attributed to inherent characteristics of SP from giant squid, i.e., the application of US is favorable to increase the EAI in squid myofibrillar protein, but not to improve the EAI of SP of the same species.

On the other hand, studies on animal and vegetable proteins (O'Sullivan et al., 2016) and milk proteins (Yanjun et al., 2014; O'Sullivan et al., 2014), indicate that the high intensity US causes a significant decrease $(\mathrm{P}<0.05)$ in the particle size (diameter), but does not reduce the size of the molecular weights in its primary structure (determined by SDS-PAGE electrophoresis), i.e., the cavitation caused by US is not enough to break the peptide bonds in the primary structure of a protein, it only generates physical ruptures, like electrostatic and hydrophobic interactions of the protein aggregates. Therefore, in the present study, the decrease of the EAI after the application of US ( $20 \mathrm{kHz}, 20 \%$ amplitude) could be due to 2 factors: i) rearrangement of amino acid residues caused by cavitation, which, in addition, of reducing the size of SP, it could expose less hydrophobic residues than their native state (control), and therefore, had a lower interaction with the oil in the interface of the emulsion, this generated less turbidity and, thus, a lower EAI, and ii) the aminoacidic composition of the SP, since these proteins, being highly soluble in water, possess more hydrophilic residues (lysine, arginine, aspartic acid, serine, etc.) than hydrophobic (leucine, valine, phenylalanine, etc.) compared to myofibrillar and stromal proteins (He et al., 2013), that even after the application of US, possibly the hydrophobic residues were not exposed in higher concentration than their initial state (control), therefore, there was less interaction with the oil.

\subsection{Emulsifying stability index}

The emulsifying stability index (ESI) indicates the time that the emulsion remains, reflecting the ability of the protein to stabilize it and delay the aggregation of oil droplets (Damodaran, 2008). The ESI of the present study is shown in Figure 2, where significant differences were found $(\mathrm{P}<0.05)$ after applying different US times on the SP of giant squid. The SP (control) presented an ESI of 152.35 min, being significantly lower $(P<0.05)$ than the SP subjected to US. That is, the application of US for 30,60 and $90 \mathrm{~s}$ increased the ESI of the PS. Wu (2001) reported that reducing the particle size of gluten proteins (from about $80 \mu \mathrm{m}$ to less than $15 \mu \mathrm{m}$ ) can increase their activity and emulsifying stability. Therefore, it is possible that the increased stability is associated

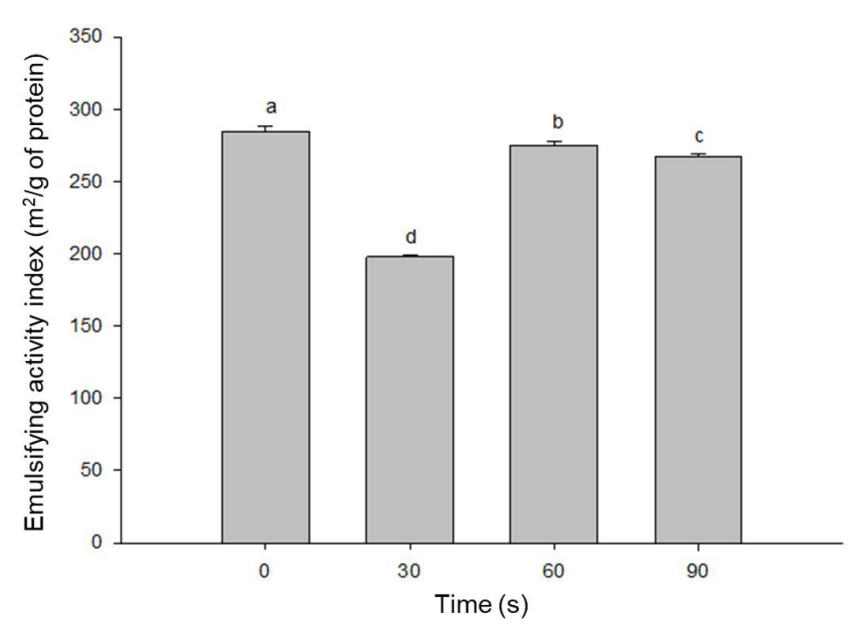

Figure 1. Effect of ultrasound on the emulsifying activity index (EAI) of sarcoplasmic proteins from giant squid (Dosidicus gigas) mantle. Different letters on bars indicate significant differences $(\mathrm{p}<0.05)$.

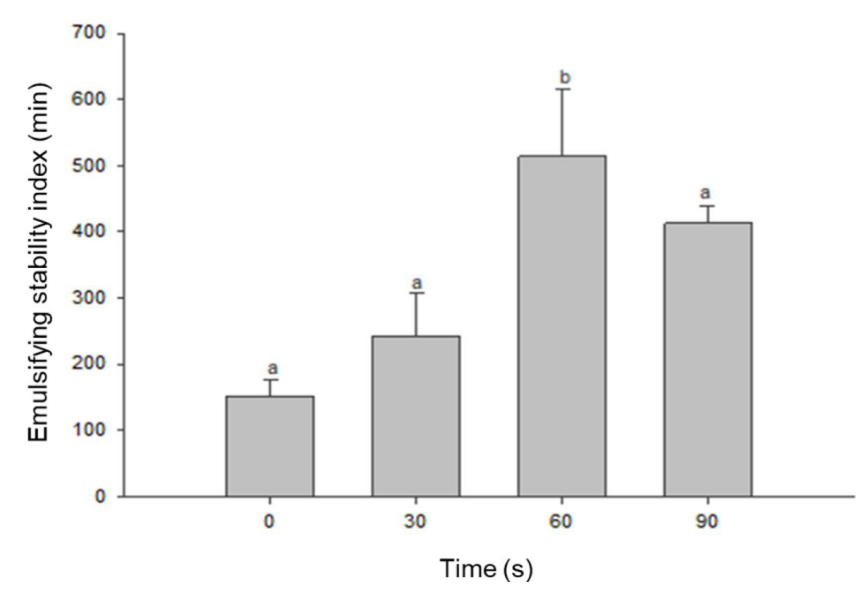

Figure 2. Effect of ultrasound on the emulsifying stability index (ESI) of sarcoplasmic proteins from giant squid (Dosidicus gigas) mantle. Data represent the mean \pm standard deviation $(n=3)$. Different letters on bars indicate significant differences $(\mathrm{p}<0.05)$.

with the reduction of the particle size. Thus, the increase in the stability may be associated with reduction in the particle size as consequence of the cavitation phenomenon by application of US, which, it is an important factor for the significant increase of the ESI.

\subsection{Foaming capacity}

The foaming capacity (FC) of proteins indicates the percentage ratio of the volume of foam formed, in relation to its initial volume (Singh et al., 2018). The FC of the SP treated with US is shown in Figure 3. Significant differences existed $(\mathrm{P}<0.05)$, since the application of US increased the FC, being higher after $30 \mathrm{~s}$ of US. The FC of the present study was superior to that reported by Mohan et al. (2006), who worked with SP (without US application) of rohu (Labeo rohita) using a concentration of $2.5 \mathrm{mg} / \mathrm{mL}$, similar to that used in the present study $(3 \mathrm{mg} / \mathrm{mL})$. This difference can be attributed to the beneficial effect of the US application in 


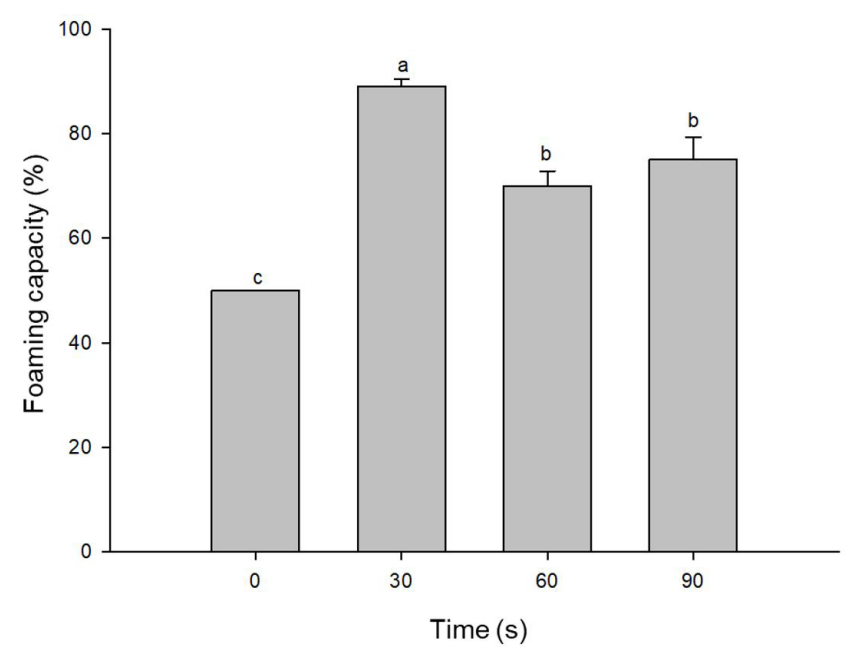

Figure 3. Effect of ultrasound on the foaming capacity (FC) of sarcoplasmic proteins from giant squid (Dosidicus gigas) mantle. Data represent the mean \pm standard deviation $(n=3)$. Different letters on bars indicate significant differences $(\mathrm{p}<0.05)$.

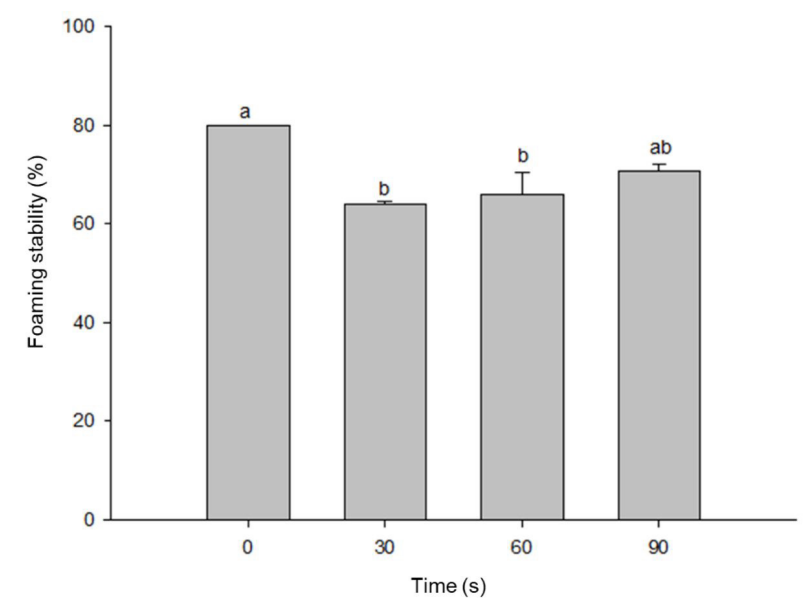

Figure 4. Effect of ultrasound on the foaming stability (FS) of sarcoplasmic proteins from giant squid (Dosidicus gigas) mantle. Data represent the mean \pm standard deviation $(n=3)$. Different letters on bars indicate significant differences $(\mathrm{p}<0.05)$.

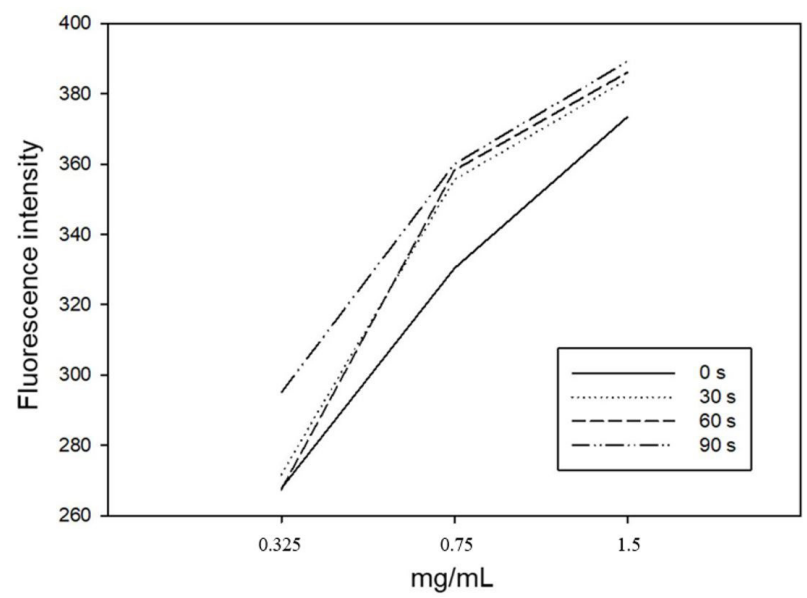

Figure 5. Effect of ultrasound on surface hydrophobicity of sarcoplasmic proteins from giant squid (Dosidicus gigas) mantle. order to increase the FC. In another study, Morales et al. (2015) applied ultrasounds (during 5, 10, 15 and $20 \mathrm{~min}$ ) in order to observe the modification of the foaming properties in isolates of soy proteins, finding that the FC increased significantly at $5 \mathrm{~min}$, increasing by $62 \%$ with respect to the untreated protein. Similar results have been reported by Jambrak et al. (2008), who studied whey proteins $(10 \%)$.

It is difficult to make an accurate comparison in terms of FC, since the evaluation technique is influenced by the protein concentration, stirring time, diameter of the test cylinder (to see the formation of foam), among others. These variables can affect the result and make it difficult to extrapolate to compare the FC with other proteins, therefore, the present study compares only the effect of the US application time on the SP from giant squid.

\subsection{Foaming stability}

The foaming stability (FS) reflects the foam ability to resist its breaking or collapse under the influence of gravity, this property depends on the flexibility and mechanical strength of the protein film at the interface (Sikorski, 2007; Yanjun et al., 2014), likewise, a film of thick, elastic, cohesive, continuous protein and impermeable to the air around each bubble is required. Figure 4 shows the FS of the SP of the giant squid after the application of US. Significant differences were found $(\mathrm{P}<0.05)$ in the FS, where the SP (control) presented a FS of $80.0 \%$, being higher than the rest of treatments. That is, under the experimental conditions used in this research the US application slightly reduced the FS. Similar results were reported by López-Enriquez et al. (2015), who reported the good stability of the SP of the squid mantle. This behavior is to be expected, since treatments with US application showed a higher FC, so it is expected that treatments with high FC present low FS.

\subsection{Surface hydrophobicity}

Surface hydrophobicity (So) is a measure of protein unfolding and this in turn is related to its functional properties (Hu et al., 2013). Figure 5 shows the increase in surface hydrophobicity of the SP according to their protein concentration, reflecting the fluorescence intensity (FI) generated by interaction between the ANS and the hydrophobic regions of proteins. As it can be seen, there is a significant increase in hydrophobicity in SP subjected to US, being slightly greater for $90 \mathrm{~s}$ of treatment. The increase in So indicates a protein unfolding, favoring the exposure of hydrophobic residues, which were not shown in their native state (Escalante-Rodriguez et al., 2018). Therefore, the application of US modifies and increases the surface hydrophobicity of the SP. A similar behaviors have been found by Arzeni et al. (2012), who working with egg proteins determined the effect of the application of US on on surface hydrophobicity. These researchers found an increase after the sonication treatment, which suggests an exposure of aromatic residues to the aqueous environment.

The increase in So could suppose an increase in EAI, since it could presume a greater number of hydrophobic groups to 
interact with the oil phase, however, there was no increase in EAI, but rather, a decrease. Studies conducted by Mignino et al. (2008), as well as by Mohan et al. (2006), show that an increase in So is not necessarily associated with an increase in EAI. In another study, Kato et al. (1983) reported a good correlation for globulins $(r=0.92)$, lactoglobulins $(r=0.99)$ and serum albumins $(r=0.93)$, but not for $k$-caseins. On the other hand, the increase in So found in the present investigation, could cause a better protein-protein interaction, which could favor the stability of the formed emulsions, as shown in Figure 2.

\subsection{Viscosity}

The viscosity values for the SP as a function of the temperature and the US treatment are shown in Figure 6. A similar behavior is observed in all the samples, a decrease in the viscosity as a function of the temperature increase. Similar results have been described by Pan et al. (2011) with carp protein (Hipophthalmichthys mollitrix), who attributed this behavior to the rupture of hydrogen bonds and electrostatic interactions between proteins. This behavior could be attributed to two factors: i) the formation of aggregates due to thermal denaturation, and ii) a high enzymatic activity exhibited by the aqueous extract (as SP) of the squid mantle (Ezquerra-Brauer et al., 2002). Likewise, a small increase in viscosity was observed between 40 and $50^{\circ} \mathrm{C}$, possibly due to the beginning of the gelation of SP, as reported by Kim et al. (2005), where $49.8^{\circ} \mathrm{C}$ is the transition temperature for squid SP (Illex argentinus) (Paredi et al., 1996).

In general terms, the rheological behavior of all treatments was similar; however, there are significant differences between sonicated and no sonicated samples. This difference lies in a displacement of the main peaks detected. For example: in the control, a peak was detected at $46.1^{\circ} \mathrm{C}$, while in the pulsed samples this peak was detected at $47.5^{\circ} \mathrm{C}$. The above indicates a conformational change for the pulsed treatment, which could be responsible for improvements in the emulsifying stability and foaming capacity. In turn, this conformational change could be explained by a slight increase in surface hydrophobicity.

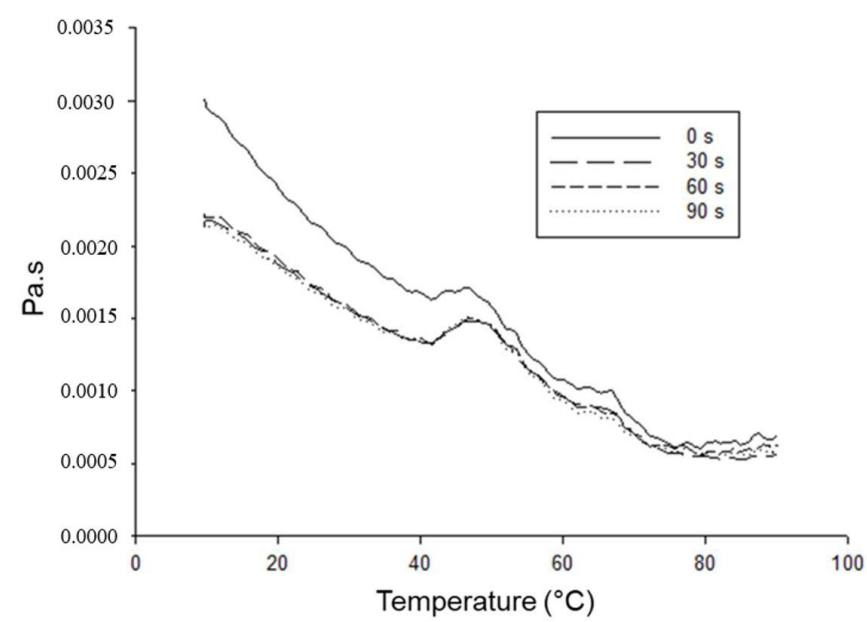

Figure 6. Effect of ultrasound on viscosity of sarcoplasmic proteins from giant squid (Dosidicus gigas) mantle.

\section{Conclusions}

The application of high intensity ultrasound ( $20 \mathrm{kHz}$ by 30,60 and $90 \mathrm{~s}$ ) on the sarcoplasmic proteins of the squid mantle (Dosidicus gigas) has a significant effect on functional properties. The application of US slightly affected the emulsifying activity index and the foaming stability. Nevertheless, the US treatment significantly improved the emulsifying stability index and the foaming capacity. This behavior is associated with an increase in surface hydrophobicity and a decrease in the viscosity of the protein system.

\section{References}

Ahmad, T., Butt, M. Z., Aadil, R. M., \& Inam-Ur-Raheem, M., Abdullah, Bekhit, A.E., Guimarães, J. T., Balthazar, C. F., Rocha, R. S., Esmerino, E. A., Freitas, M. Q., Silva, M. C., Sameen, A., \& Cruz, A. G. (2019). Impact of nonthermal processing on different milk enzymes. International Journal of Dairy Technology, 72(4), 481-495. http:// http://dx.doi.org/10.1111/1471-0307.12622.

Amiri, A., Sharifian, P., \& Soltanizadeh, N. (2018). Application of ultrasound treatment for improving the physicochemical, functional and rheological properties of myofibrillar proteins. International Journal of Biological Macromolecules, 111, 139-147. http://dx.doi. org/10.1016/j.ijbiomac.2017.12.167. PMid:29307807.

Arzeni, C., Pérez, O. E., \& Pilosof, A. M. R. (2012). Functionality of egg white proteins as affected by high intensity ultrasound. Food Hydrocolloids, 29(2), 308-316. http://dx.doi.org/10.1016/j. foodhyd.2012.03.009.

Balthazar, C. F., Santillo, A., Guimarães, J. T., Bevilacqua, A., Corbo, M. R., Caroprese, M., Marino, R., Esmerino, E. A., Silva, M. C., Raices, R. S. L., Freitas, M. Q., Cruz, A. G., \& Albenzio, M. (2019). Ultrasound processing of fresh and frozen semi-skimmed sheep milk and its effects on microbiological and physical-chemical quality. Ultrasonics Sonochemistry, 51, 241-248. http://dx.doi.org/10.1016/j. ultsonch.2018.10.017. PMid:30377079.

Coffmann, C. W., \& Garciaj, V. V. (1977). Functional properties and amino acid content of protein isolate from mungbean flour. Journal of Food Technology, 12(5), 473-484. http://dx.doi.org/10.1111/j.1365-2621.1977. tb00132.x.

Damodaran, S. (2008). Aminoacids, peptides, and proteins. In S. Damodaran, K. L. Parkin, \& O.R. Fennema (Eds.), Fennema's food chemistry (pp. 217-330). New York: CRC Press.

Dihort-Garcia, G., Ocano-Higuera, V. M., Ezquerra-Brauer, J. M., Lugo-Sanchez, M. E., Pacheco-Aguilar, R., Barrales-Heredia, S. M., \& Marquez-Rios, E. (2011). Production and functional evaluation of a protein concentrate from giant squid (Dosidicus gigas) obtained by alkaline dissolution. CYTA: Journal of Food, 9(3), 171-179. http:// dx.doi.org/10.1080/19476337.2010.503905.

Encinas-Arzate, J. J., Ezquerra-Brauer, J. M., Ocaño-Higuera, V. M., Ramirez-Wong, B., Armenta-Villegas, L., Torres-Arreaola, W., \& Marquez-Rios, E. (2014). Effect of ionic strength on soluble protein removal from giant squid mantle (Dosidicus gigas) and functional evaluation of protein recovery. Food Science and Biotechnology, 23(2), 401-407. http://dx.doi.org/10.1007/s10068-014-0055-y.

Escalante-Rodriguez, M. F., Murrieta-Martinez, C. L., Ocaño-Higuera, V. M., Ramirez-Wong, B., Ruiz-Cruz, S., Rodriguez-Olibarria, G., \& Marquez-Rios, E. (2018). Effect of setting on the gelling properties of a protein concentrate from giant squid (Dosidicus gigas) mantle. 
Food Science and Technology (Campinas), 38(3), 467-472. http:// dx.doi.org/10.1590/fst.01717.

Ezquerra-Brauer, J. M., Haard, N., Ramirez-Olivas, R., Olivas-Burrola, H., \& Velazquez-Sánchez, C. J. (2002). Influence of harvest season on the proteolytic activity of hepatopancreas and mantle tissues from jumbo squid (Dosidicus gigas). Journal of Food Biochemistry, 26(5), 459-475. http://dx.doi.org/10.1111/j.1745-4514.2002.tb00766.x.

Guimarães, J. T., Balthazar, C. F., Scudino, H., Pimentel, T. C., Esmerino, E. A., Ashokkumar, M., Freitas, M. Q., \& Cruz, A. G. (2019a). Highintensity ultrasound: a novel technology for the development of probiotic and prebiotic dairy products. Ultrasonics Sonochemistry, 57, 12-21. http://dx.doi.org/10.1016/j.ultsonch.2019.05.004. PMid:31208607.

Guimarães, J. T., Silva, E. K., Ranadheera, C. S., Moraes, J., Raices, R. S. L., Silva, M. C., Ferreira, M. S., Freitas, M. Q., Meireles, M. A. A., \& Cruz, A. G. (2019b). Effect of high-intensity ultrasound on the nutritional profile and volatile compounds of a prebiotic soursop whey beverage. Ultrasonics Sonochemistry, 55, 157-164. http://dx.doi. org/10.1016/j.ultsonch.2019.02.025. PMid:30853535.

He, X., Cao, W., Zhao, Z., \& Zhang, C. (2013). Analysis of protein composition and antioxidant activity of hydrolysates from Paphia undulate. Journal of Food and Nutrition Research, 1(3), 30-36. http:// dx.doi.org/10.12691/jfnr-1-3-3.

Higuera-Barraza, O. A., Del Toro-Sanchez, C. L., Ruiz-Cruz, S., \& Marquez-Rios, E. (2016). Effect of high-energy utrasound on the functional properties of proteins. Ultrasonics Sonochemistry, 31, 558562. http://dx.doi.org/10.1016/j.ultsonch.2016.02.007. PMid:26964983.

Higuera-Barraza, O. A., Torres-Arreola, W., Ezquerra-Brauer, J. M., Cinco-Moroyoqui, F. J., Rodríguez-Figueroa, J. C., \& MarquezRios, E. (2017). Effect of pulsed ultrasound on the physicochemical characteristics and emulsifying properties of squid (Dosidicus gigas) mantle proteins. Ultrasonics Sonochemistry, 38, 829-834. http://dx.doi. org/10.1016/j.ultsonch.2017.01.008. PMid:28109677.

Hu, H., Wu, J., Li-Chan, E. C. Y., Zhu, L., Zhang, F., Xu, X., Fan, G., Wang, L., Huang, X., \& Pan, S. (2013). Effects of ultrasound on structural and physical properties of soy protein isolate (SPI) dispersions. Food Hydrocolloids, 30(2), 647-655. http://dx.doi.org/10.1016/j. foodhyd.2012.08.001.

Jambrak, A. R., Mason, T. J., Lelas, V., Herceg, Z., \& Herceg, I. L. (2008). Effect of ultrasound treatment on solubility and foaming properties of whey protein suspensions. Journal of Food Engineering, 86(2), 281-287. http://dx.doi.org/10.1016/j.jfoodeng.2007.10.004.

Kato, A., \& Nakai, S. (1980). Hydrophobicity determined by a fluorescence probe method and its correlation with surface properties of proteins. Biochimica et Biophysica Acta, 624(1), 13-20. http://dx.doi. org/10.1016/0005-2795(80)90220-2. PMid:7407231.

Kato, A., Osako, Y., Matsudomi, N., \& Kobayashi, K. (1983). Changes in the emulsifying and foaming properties of proteins during heat denaturation. Agricultural and Biological Chemistry, 47, 33-37. http:// dx.doi.org/10.1080/00021369.1983.10865579.

Khairi, M. T. O., Ibrahim, S., Yunus, A. M. M. D., \& Faramarzi, M. (2018). Ultrasonic tomography for detecting foreign objects in refrigerated milk cartons. International Journal of Dairy Technology, 71(4), 1005-1011. http:// dx.doi.org/10.1111/1471-0307.12534.

Kim, Y. S., Yongsawatdigul, J., Park, J. W., \& Thawornchinsombut, S. (2005). Characteristics of sarcoplasmic proteins and their interaction with myofibrillar proteins. Journal of Food Biochemistry, 29(5), 517532. http://dx.doi.org/10.1111/j.1745-4514.2005.00023.x.
López-Enriquez, R. L., Ocano-Higuera, V. M., Torres-Arreola, W., Ezquerra-Brauer, J. M., \& Marquez-Rios, E. (2015). Chemical and functional characterization of sarcoplasmic proteins from giant squid (Dosidicus gigas) mantle. Journal of Chemistry, 2015, 1-10. http://dx.doi.org/10.1155/2015/538721.

Lowry, O. H., Rosebrough, N. J., Farr, A. L., \& Randall, R. J. (1951). Protein measurement with the folin phenol reagent. The Journal of Biological Chemistry, 193(1), 265-275. PMid:14907713.

Mignino, L. A., Crupkin, M., \& Paredi, M. E. (2008). Surface hydrophobicity and functional properties of myofibrillar proteins of mantle from frozen-stored squid (Illex argentinus) caught either jigging machine or trawling. Lebensmittel-Wissenschaft + Technologie, 41(4), 678-685. http://dx.doi.org/10.1016/j.lwt.2007.05.006.

Mohan, M., Ramachandran, D., \& Sankar, T. V. (2006). Functional properties of Rohu (Labeo rohita) proteins during iced storage. Food Research International, 39(8), 847-854. http://dx.doi.org/10.1016/j. foodres.2006.04.003.

Morales, R., Martínez, K. D., Pizones Ruiz-Henestrosa, V. M., \& Pilosof, A. M. R. (2015). Modification of foaming properties of soy protein isolate by high ultrasound intensity: Particle size effect. Ultrasonics Sonochemistry, 26, 48-55. http://dx.doi.org/10.1016/j. ultsonch.2015.01.011. PMid:25619451.

O'Sullivan, J., Arellano, M., Pichot, R., \& Norton, I. (2014). The effect of ultrasound treatment on the structural, physical and emulsifying properties of dairy proteins. Food Hydrocolloids, 42(3), 386-396. http://dx.doi.org/10.1016/j.foodhyd.2014.05.011.

O’Sullivan, J., Murray, B., Flynn, C., \& Norton, I. (2016). The effect of ultrasound treatment on the structural, physical and emulsifying properties of animal and vegetable proteins. Food Hydrocolloids, 53, 141-154. http://dx.doi.org/10.1016/j.foodhyd.2015.02.009.

Pan, J., Shen, H., You, J., \& Luo, Y. (2011). Changes in physiochemical properties of myofibrillar protein from silver carp (Hypophthalmichthys mollitrix) during heat treatment. Journal of Food Biochemistry, 35(3), 939-952. http://dx.doi.org/10.1111/j.1745-4514.2010.00431.x.

Paredi, M. A., Tomas, M. C., Crupkin, M., \& Añón, M. C. (1996). Thermal denaturation of muscle proteins from male and female squid (Illex argentinus) at different sexual maturation stages. A differential scanning calorimetric study. Journal of Agricultural and Food Chemistry, 44(12), 3812-3816. http://dx.doi.org/10.1021/jf960096+.

Park, J. W. (2005). Surimi and surimi seafood. New York: Taylor and Francis. http://dx.doi.org/10.1201/9781420028041.

Pearce, K. N., \& Kinsella, J. E. (1978). Emulsifying properties of proteins: evaluation of a turbidimetric technique. Journal of Agricultural and Food Chemistry, 26(3), 716-722. http://dx.doi.org/10.1021/jf60217a041.

Rodriguez-Turienzo, L., Cobos, A., \& Diaz, O. (2012). Effects of edible coating based on ultrasound-treated whey proteins in quality attributes of frozen Atlantic salmon (Salmo salar). Innovative Food Science \& Emerging Technologies, 14, 92-98. http://dx.doi.org/10.1016/j. ifset.2011.12.003.

Sett, S., Stephansen, K., \& Yarin, A. L. (2016). Solution-blown nanofiber mats from fish sarcoplasmic protein. Polymers, 93, 78-87. http:// dx.doi.org/10.1016/j.polymer.2016.04.019.

Sikorski, Z. E. 2007. The role of proteins in food. In Z. E. Sikorski (Ed.), Chemical and functional properties of food components (pp. 128-176). New York: CRC Press.

Singh, A., Benjakul, S., \& Kijroongrojana, K. (2018). Effect of ultrasonication on physicochemical and foaming properties of 
squid ovary powder. Food Hydrocolloids, 77, 286-296. http://dx.doi. org/10.1016/j.foodhyd.2017.10.005.

Tian, J., Wang, Y., Zhu, Z., Zeng, Q., \& Xin, M. (2015). Recovery of tilapia (Oreochromis niloticus) protein isolate by high-intensity ultrasound-aided alkaline isoelectric solubilization/precipitation process. Food and Bioprocess Technology, 8(4), 758-769. http:// dx.doi.org/10.1007/s11947-014-1431-6.

Valdez-Hurtado, S., López-Bermúdez, L. S., Higuera-Barraza, O. A., Del Toro-Sanchez, C. L., Ruiz-Cruz, S., Suárez-Jiménez, M. G., \& Marquez-Rios, E. (2019). Effect of ultrasonication time on the functional properties of giant squid (Dosidicus gigas) mantle protein concentrate. Food Bioscience, 27, 1-5. http://dx.doi.org/10.1016/j. fbio.2018.11.003.

Villamonte, G., Pottier, L., \& De Lamballerie, M. (2016). Influence of high-pressure processing on the physicochemical and the emulsifying properties of sarcoplasmic proteins from hake (Merluccius merluccius). European Food Research and Technology, 242(5), 667-675. http:// dx.doi.org/10.1007/s00217-015-2574-z.

Wang, J. Y., Yang, Y. L., Tang, X. Z., Ni, W. X., \& Zhou, L. (2017). Effects of pulsed ultrasound on rheological and structural properties of chicken myofibrillar protein. Ultrasonics Sonochemistry, 38, 225-233. http://dx.doi.org/10.1016/j.ultsonch.2017.03.018. PMid:28633822.

Wu, Y. V. (2001). Emulsifying activity and emulsion stability of corn gluten meal. Journal of the Science of Food and Agriculture, 81(13), 1223-1227. http://dx.doi.org/10.1002/jsfa.934.

Yang, F., Liu, X., Ren, X., Huang, Y., Huang, C., \& Zhang, K. (2018). Swirling cavitation improves the emulsifying properties of commercial soy protein isolate. Ultrasonics Sonochemistry, 42, 471-481. http:// dx.doi.org/10.1016/j.ultsonch.2017.12.014. PMid:29429693.

Yanjun, S., Jianhang, C., Shuwen, Z., Hongjuan, L., Jing, L., Lu, L., Uluko, H., Yanling, S., Wenming, C., Wupeng, G., \& Jiaping, L. (2014). Effect of power ultrasound pre-treatment on the physical and functional properties of reconstituted milk protein concentrate. Journal of Food Engineering, 24, 11-18. http://dx.doi.org/10.1016/j. jfoodeng.2013.09.013.

Yongsawatdigul, J., \& Hemung, B. (2010). Structural changes and functional properties of threadfin bream sarcoplasmic proteins subjected to $\mathrm{pH}$-shifting treatments and lyophilization. Journal of Food Science, 75(3), 251-257. http://dx.doi.org/10.1111/j.17503841.2010.01530.x. PMid:20492275. 